This item was submitted to Loughborough's Research Repository by the author.

Items in Figshare are protected by copyright, with all rights reserved, unless otherwise indicated.

\title{
Charging to enter the water shop? The costs of urban water connections for the poor
}

PLEASE CITE THE PUBLISHED VERSION

PUBLISHER

(C) WEDC, Loughborough University

\section{VERSION}

VoR (Version of Record)

\section{PUBLISHER STATEMENT}

This work is made available according to the conditions of the Creative Commons Attribution-NonCommercialNoDerivatives 4.0 International (CC BY-NC-ND 4.0) licence. Full details of this licence are available at: https://creativecommons.org/licenses/by-nc-nd/4.0/

\section{LICENCE}

CC BY-NC-ND 4.0

\section{REPOSITORY RECORD}

Franceys, Richard, and Sam Kayaga. 2019. "Charging to Enter the Water Shop? the Costs of Urban Water Connections for the Poor”. figshare. https://hdl.handle.net/2134/31689. 


\title{
Charging to enter the water shop? The costs of urban water connections for the poor
}

\author{
R. Franceys and S. Kayaga, UK
}

\begin{abstract}
A global research programme is being undertaken to investigate the actual costs and charges, formal and informal, of obtaining a water connection in urban areas. The output of this research will contribute to understanding how programmes and pricing structures to subsidize water supply for the poor can help if only the rich can afford to 'enter the water shop', that is can afford to pay for the high cost of the initial connection. Reference is made to the benefits to be gained from a household connection, in terms of reductions in infant morbidity as well as sustainable livelihoods. Recommendations are made as to appropriate strategies for utilities to consider in enabling new connections
\end{abstract}

\section{Water connections}

The research described in this paper is designed to assist the urban poor, often living in multi-occupancy tenements or compounds, in slums, shanties, unplanned and illegal settlements, who are presently paying ten to twenty times as much per cubic metre of water as the connected rich. The poorest have to rely upon vendors, presently being unable to access, for example, lifeline block subsidies because they cannot afford the costs and charges of new household water connections. However efficient vendors might be, they will usually have higher costs than a piped supply system, not being able to access the economies of scale of bulk treatment and supply.

The poor benefit most from accessing clean water at an affordable consumption charge, having first achieved household or group water connections through differentiated tariffs and mains extensions. The end users typically survive at present on less than $\$ 2$ per day and typically consist of between $20 \%$ and $50 \%$ of the 2,083 million population urban areas in low and middle income countries. Because of this level of poverty the poor are unable to build up any reasonable level of capital to invest in one-off major payments for connections but the evidence suggests that they are able to pay small on-going charges at a level similar to the cost of supplying water. They then benefit from the convenience and cost savings of piped water.

The benefits can be significant, in economic terms and in health terms. One study reports that child mortality fell by $24 \%$ in the poorest municipalities as a result of increased household connections in Argentina (Galiani et al, 2002). In Asia, focus groups (of women) report the benefits that are achievable as a result of gaining household connections in poor areas, following regulatory facilitation of operators.

One householder in Jakarta, Indonesia says that, 'after having a new water supply connection, she opened a small kiosk in her home and sells ice cubes'. Others described how the revenue generated from starting a small boarding house and similar activities outweighs the cost of paying their water bill. One woman resident in Manila, Philippines described 'spending up to P40 pesos per day for water bought from a vendor and now pays only P25 to P50 per month, a 96\% reduction'. The group of women mentioned other benefits: 'more time available to them which now they can use for other household chores; and even time for leisure such as going to the malls; no more stress from queuing (where rows often occurred when others do not follow the queues leading to so much stress) and waiting for water to become available; no more waking up at 3:00 a.m. to queue; more money for other household needs, and can now take a shower' (Weitz \& Franceys, 2002).

Any discussion relating to water and charging usually runs up against the politicians ' unwillingness to charge'. We have included politicians in our target group for this research to determine whether changes to connection charges might be seen as an opportunity or a threat. Initial discussions with one mayor, the Chairperson of the town of Ramagundam (pop 250,000) in India, who himself has already begun to experiment with altering connection charges with some success suggests that the willingness to charge appropriate connection tariffs is not nearly as sensitive an issue politically as the willingness to charge viable consumption tariffs. We understand that it is politically advantageous to be able to promote lower connection charges - the longer-term challenge for the water utility is to ensure that the overall costs are still recovered through equitable re-balancing to ensure financial sustainability.

We are aware of the financial and institutional challenge in getting tariffs correct but we see enhanced benefits for utilities in obtaining additional revenue from 'new' customers who might have traditionally been using utility water without pay- 
ing for it (often by means of vendor intermediaries or illegal connections). This additional cash flow should be valuable as utilities invest to expand their service coverage.

The private operators demonstrate how this increased cash flow can be invested in leak detection which in some cases has led to an apparent overcapacity in production which ensures availability of water for the new customers and therefore does not impact on scarce water resources which otherwise might have been seen as a negative environmental impact.

The issue of affordable connection charges has to date been addressed most often where the private sector become involved (as in the benefits reported above from Manila and Jakarta) and where the urgent needs for increased service coverage, increased revenue and the enhanced awareness of such issues by civil society come to the fore. For example, the water regulator in Buenos Aires agreed that the average connection charge of over $\$ 500$ for water plus more than $\$ 1000$ for sewerage should be reduced to $\$ 120$ for both services, amortized over several years, supported by a universal charge on all other customers of $\$ 2$ per month. In Buenos Aires this has led to a significant increase in connections to the poor. There are other cost sharing ideas being experimented with in other parts of the world with the potential of using micro-credit facilities through NGOs for connection costs as is now being achieved for telecoms for the poorest.

The poor in areas worldwide where the private sector is not yet involved also need to benefit in the same way. Governments and their utility providers would gain from having more information about this issue with clear distinctions made between the need for recovering a development charge, that is the capital cost of the distribution network, recovering a connection charge, that is the marginal cost of connection, metering and billing, needing a deposit for future consumption charges, delegating physical costs to licensed plumbers with competition over costs, allowing urban local bodies to make a return from road-cutting charges, all to be contrasted against the development benefits of making it easy for consumers to access the public health benefits of a convenient water supply, all with easy payment terms to make that possible.

\section{Researching connection charges}

The research problem is the lack of verifiable knowledge and understanding amongst government water utilities regarding the specific role of connection charges, which when linked to physical connection costs, make household connections unaffordable to the poor. This is a specific problem which has tended to be lost in the larger issues of tariff policy public private partnerships and regulation etc but which has a direct impact on the poor with potential for early benefits

Connection charges (the fees the utility charges) and connection costs (the physical costs households have to pay for pipes etc) are often beyond the ability to pay of poor users (assuming that there are water mains to connect to in the vicinity). High connection charges often appear to be designed as a barrier to entry, to limit demand on a precarious water system. An alternative explanation is that they maximise illegal on-selling of water to vendors by utility staff. Addressing the implications of connection charges and costs is therefore critical to enable the poor to acquire the benefits of public investment.

At present there is only a limited available literature on connection charges - as opposed to consumption tariffs where there has been a lot of research. The International Water Association (Pocock, 2002)) for example in its 'Water Pricing as a Key Element in a Sustainable Strategy' research considers the role of price subsidy - 'a complex issue'; price elasticity - 'a complex topic'; the effect of rising-block and cost reflective tariffs - 'inconsistent between communities'. However, it does not address the specific problem of connection charges which has become most apparent in the work of the private operators around the world as they have tried to develop new approaches to serving the poor.

There has been earlier work on marginal costing of network connections, usually with a focus on electricity connections. There is useful work on delivering and maintaining utility services to the poor, for example Lovei, et al (2000) and work on the benefits of urban connections to services (Shi, 2000) as well as Galiani et al (2002) quoted earlier.

There is ongoing work into differentiating service levels in order to ensure affordable ongoing water delivery to the poor as in the work in El Alto, Bolivia reported on by World Bank and WSP as well as Sansom et al (2004) but these do not focus upon the challenge utilities have in sorting out connection charges.

Estache et al (2000) take an economists overview of the costs and benefits of improved and formalised connections to the poor for various types of network utilities in Latin America, referring to the challenge of getting connections costs correct without going into the practical details of that for the water sector.

The literature referred to here and additional references suggest that there has never been any particularly systematic approach to connection charges. Unlike the established methods for consumption charges, connection charges appear to have developed over time in a very location specific manner with no particular underlying theory. Sometimes it would appear that they have been designed deliberately to act as a 'barrier to entry', to prevent new consumers threatening scarce water resources or to prevent low-income consumers being unable to consequently pay consumption charges. For others it appears that the original reasons have been lost in 'the mists of time' with occasional increases due to inflation leading to the present charges.

\section{Investigating actual connection costs and charges}

The initial research methodology employed has been a survey of existing connections charges and costs (direct and indirect), undertaken by our international research partners in Asia (ASCI, India and Philippine Centre for Water and 
Sanitation) and Africa (Uganda through WEDC and Ghana through Kwameh Nkrumah University of Science and Technology). Following the global overview of data, and the initial analysis of the key factors, we selected representative towns and cities where our partners undertook detailed surveys of newly connected lower-income customers through questionnaires and focus groups. It is, not surprisingly, difficult to investigate what the poor have paid to connect as, almost by our definition, they cannot afford to connect. We therefore tried to select respondents from the lowest-income level who can afford to connect to find out what they actually paid and how these various costs and charges were financed in order to propose more effective ways for the future.

We were able to map an overview of the connection process, looking at both formal and informal costs and charges, which has worked surprisingly well across different countries and continents. In describing it below it is most unlikely that all these elements are found everywhere. Research to date tends to show that it is a haphazard selection from this list.

\section{The water connection process}

The starting point is acquiring the Application Form which can require a formal fee, with the potential for an informal request/thank you payment. Completing this form may require a payment to a local councillor to gain their approval, payment to the landlord for proof of land ownership and/or payment for an approval letter from the pipe owner/community water association who may well have paid for an 'alternative' mains extension.

Submitting the completed Application Form with its necessary supporting documents can require payment of a Connection Fee which might include a substantial part of the costs of physical connection outlined below or may simply be an administrative fee or a contribution to mains extension costs described early. At this stage there is again the possibility of having to pay 'speed money' to gain timely acceptance of the application as well as the on-going opportunity costs of the time taken to travel to the appropriate water utility office which may well be in the centre of the city.

Submission of the application might well trigger a visit by the utility surveyor to check the location and the proximity to the water main which can require an additional survey fee in addition to associated costs of perhaps paying for transport for the surveyor as well as snacks and encouragement money.

The purpose of describing the process in such detail is not to suggest that the utilities are in any way particularly deficient in their processes but rather to show what a significant hurdle obtaining a water connection can be to a daily paid occasional labourer perhaps renting a room or two on a barely 'legal' housing development. But it is precisely these households who can benefit most dramatically from the convenience and lower consumption cost of a suitable connection.

Following the acceptance of the application, which might require 'speed money', there is the need to obtain the mains-tapping or ferrule connector, the communication pipe, meter and stop cock, perhaps from an 'approved' supplier (where costs will be slightly higher) or perhaps included as part of the connection fee. Then comes the labour charges for trench digging, probably including snacks for water utility staff working overtime or at weekends to install the pipework to the satisfaction of any Inspector who might also require transporting or compensating. If the householder is 'unlucky', the mains to connect into will be on the other side of the surfaced roadway and therefore the householder will be liable to 'road-cutting charges' which include for reinstatement to a suitable standard, which might require approval by a different, roads, inspector. The final meter installation and/or counting of taps to determine tariff levels could also require a final visit with associated informal costs. Or if suitable payment is made this visit can be delayed for a period to allow for unmetered consumption until the meter installer/reader 'has time to install the meter.'

Some households, though probably not the target lowerincome households ('developing poor households'), will want to add to these costs the actual in-house pipework and sanitary fittings and, depending upon the quality and hours of supply, will consider the additional costs of small pumps to suck the water out of the mains (at the expense of nonpumping neighbours), ground tanks to store the water when it occasionally arrives and potentially an additional pump to a roof level tank to give the convenience of reasonable pressure taps in a variety of household locations.

All of the above need financing in some ways which implies additional costs of borrowing for low-income consumers. Is it any wonder that the poor have to rely upon vendors or neighbours charging several times more than the official volumetric lifeline charge?

\section{The Uganda field research}

Fieldwork was carried out in January 2004 in two of Uganda's largest towns of Jinja (2002 population of 413,937) and Kampala (2002 population of 1,208,504). A survey was conducted with 43 customers, representing a probability sample from newly connected customers in the previous six months. Table 1 shows a summary of the profile of direct and indirect costs incurred by the customers in the process of obtaining a water connection.

\section{Conclusion}

The results of the Uganda research demonstrate the substantial and unpredictable nature of the costs involved in obtaining a new water connection, costs which are too risky as well as unaffordable as capital sums by the poorest - a mean of $\$ 313$ for a 'dollar a day' household), service for whom the public management of water supply must be the goal. Water utilities need to adjust their new connection policies, reducing any charges and including costs in an 'all-in' approach already used by some, with costs amortised over several years, perhaps learning from the cable television and mobile phone operators who seem to have a different view of the 


\begin{tabular}{|c|c|c|c|}
\hline \multicolumn{4}{|c|}{$\begin{array}{l}\text { Table 1.Costs, in Uganda Shillings, incurred on new } \\
\text { connections in Jinja and Kampala (Uganda Shs. } 2000= \\
1 \text { US\$). }\end{array}$} \\
\hline Type of costs & Range & Mean & SD \\
\hline Costs before approval & 198,500 & 26,000 & 53,400 \\
\hline Costs on surveying & 300,000 & 14,800 & 46,800 \\
\hline Connection fee & 158,500 & 67,600 & 21,800 \\
\hline Costs of materials & $5,800,000$ & 308,800 & 870,700 \\
\hline Transport expenses & 60,000 & 8,200 & 15,200 \\
\hline Road cutting charges & 200,000 & 10,200 & 37,900 \\
\hline $\begin{array}{l}\text { Labour for trenching \& } \\
\text { pipe-laying }\end{array}$ & $2,557,000$ & 171,900 & 530,700 \\
\hline Snacks for labourers & 34,000 & 2,700 & 6,700 \\
\hline $\begin{array}{l}\text { Opportunity cost of } \\
\text { personal involvement }\end{array}$ & 90,000 & 8,300 & 18,900 \\
\hline $\begin{array}{l}\text { Speed money after } \\
\text { connection }\end{array}$ & 20,000 & 1,040 & 3,800 \\
\hline $\begin{array}{l}\text { Informal meter } \\
\text { charges }\end{array}$ & 40,000 & 1,900 & 7,300 \\
\hline Total costs & $8,363,000$ & 626,400 & $1,325,000$ \\
\hline
\end{tabular}

costs and benefits of signing up new customers.

\section{Acknowledgments}

"This document is an output from a project funded by the UK Department for International Development (DFID) for the benefit of developing countries. The views expressed are not necessarily those of DFID" The authors would like to stress their appreciation of the efforts of all members of the international research team.

\section{References}

Estache A., Gomez-Lobo, A., Leipziger, D., (2000), "Utilities 'Privatization' and the Poor's Needs in Latin America: Have we learned enough to get it right?" Infrastructure Development, London
Galiani, S., Gertler, P. and Schargrodsky, E., (2002) Water for life: The impact of the privatization of water services on child mortality, Center for Research on Economic Development and Policy Reform, Stanford.

Lovei, L., Gurenko, E., Haney, M., O’Keefe, P., Shkaratan, M., (2000), 'Maintaining Utility Services for the Poor', World Bank, Washington DC

Pocock, M., (2002), 'Water Pricing as a Key Element in a Sustainable Strategy', International Water Association, MIA Specialist Group, London

Sansom, K., Franceys, R., Njiru, C., Kayaga, S., Coates, S., and Chary S., (2004), 'Serving All Urban Consumers', WEDC, Loughborough University.

Shi, A., (2000), 'How Access to Urban Potable Water and Sewerage Connections Affects Child Mortality', Working Papers - Environment, World Bank, Washington DC

Weitz, A. and Franceys, R., (2002), 'Beyond boundaries: extending services to the urban poor', Asian Development Bank, Manila.

\section{Contact address}

Dr Richard Franceys

Senior Lecturer in Water and Sanitation Management Institute of Water and Environment

Cranfield University, UK

e-mail: r.w.a.franceys@cranfield.ac.uk

\section{Dr Sam Kayaga}

Research Associate

WEDC

Loughborough University, UK

e-mail: s.m.kayaga@lboro.ac.uk 